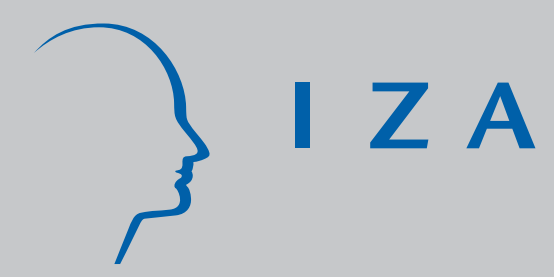

IZA DP No. 2422

Mexican-Hispanic Self-Employment Entry:

The Role of Business Start-Up Constraints

Magnus Lofstrom

Chunbei Wang

November 2006 


\title{
Mexican-Hispanic Self-Employment Entry: The Role of Business Start-Up Constraints
}

\author{
Magnus Lofstrom \\ University of Texas at Dallas \\ and IZA Bonn \\ Chunbei Wang \\ University of Texas at Dallas
}

\section{Discussion Paper No. 2422 \\ November 2006}

\author{
IZA \\ P.O. Box 7240 \\ 53072 Bonn \\ Germany \\ Phone: +49-228-3894-0 \\ Fax: +49-228-3894-180 \\ E-mail: iza@iza.org
}

\begin{abstract}
Any opinions expressed here are those of the author(s) and not those of the institute. Research disseminated by IZA may include views on policy, but the institute itself takes no institutional policy positions.

The Institute for the Study of Labor (IZA) in Bonn is a local and virtual international research center and a place of communication between science, politics and business. IZA is an independent nonprofit company supported by Deutsche Post World Net. The center is associated with the University of Bonn and offers a stimulating research environment through its research networks, research support, and visitors and doctoral programs. IZA engages in (i) original and internationally competitive research in all fields of labor economics, (ii) development of policy concepts, and (iii) dissemination of research results and concepts to the interested public.
\end{abstract}

IZA Discussion Papers often represent preliminary work and are circulated to encourage discussion. Citation of such a paper should account for its provisional character. A revised version may be available directly from the author. 
IZA Discussion Paper No. 2422

November 2006

\section{ABSTRACT}

\section{Mexican-Hispanic Self-Employment Entry: The Role of Business Start-Up Constraints}

This paper examines causes of the low self-employment rates among Mexican-Hispanics by studying self-employment entry utilizing the 1996 panel of the Survey of Income and Program Participation (SIPP). The data show that Mexican-Hispanics are less likely to be selfemployed as well as entering self-employment, relative to non-Hispanic whites. Importantly, we analyze self-employment by recognizing heterogeneity in business ownership across industries and show that a classification of firms by human and financial capital "intensiveness", or entry barriers, is effective in explaining differences in entrepreneurship across ethnic groups. We show that the lower self-employment entry rates among MexicanHispanics are due to lower entry rates into business ownership of firms in relatively highbarrier industries. In fact, Hispanics are more likely to start-up a business in a low-barrier industry than whites.

JEL Classification: J15, J23

Keywords: self-employment, entrepreneurship, Hispanic

Corresponding author:

Magnus Lofstrom

University of Texas at Dallas

School of Social Sciences

P.O. Box 830688

GR 31

Richardson, TX 75083-0688

USA

E-mail: lofstrom@utdallas.edu

\footnotetext{
* We thank Tim Bates, participants at the first Entrepreneurship Boot Camp and the Conference on Enterpreneurship among Minorities and Women for helpful comments. Funding from the Ewing M. Kauffman foundation is gratefully acknowledged.
} 


\section{Introduction}

Mexican-Hispanics are substantially less likely to be self-employed compared to non-Hispanic whites. Specifically, male Mexican-Hispanic self-employment rates are one-half of the self-employment rates of whites, about 8 and 16 percent respectively, a similar difference in self-employment rates as the one between whites and AfricanAmericans. Not surprisingly, the significantly lower minority self-employment rates are recognized by policy makers. The presence of a large number of government programs intended to increase business ownership among minorities, such as set-asides and loans to minorities, shows policy makers' concern with the lower minority, including Hispanics, self-employment rates and suggests a perception of existing business ownership constraint that leads to some degree of economic inefficiency in the absence of market interventions (see, for example, Bates, 1993, for a discussion of some of the programs and their success). Two potentially contributing factors to the low Mexican-Hispanic selfemployment rates are the ir relatively low levels of educational attainment and limited access to financial capital. These constraints are likely to manifest themselves in differences across ethnic groups in the industries sought to enter. In this paper, we seek to address the role of industries and business start-up constraints faced by minorities in explaining the gap in self-employment rates between non-Hispanic whites and MexicanHispanics.

Up to now, research on Hispanic self-employment has not received nearly the same attention as African-American entrepreneurship. Hispanics are of particular interest given the fact that this is the fastest growing ethnic group in the U.S., primarily fueled by 
immigration from Mexico, and now represents almost 14 percent of the U.S. population, slightly greater than the proportion of non-Hispanic blacks (Statistical Abstracts of the U.S., 2006). Like African-Americans, Hispanics are a disadvantaged minority group, but there are a number of differences between the two groups, particularly regarding family composition, educational attainment, immigration status and historical experiences in the U.S. Given this, and the size and growth of Hispanics in the U.S., this important ethnic group deserves separate attention. In this paper, we focus our analysis on the largest Hispanic group in the U.S., Mexican-Hispanics.

Our descriptive analysis shows that differences in industry composition across groups are significant in explaining business start-up differences between MexicanHispanics and non-Hispanic white males. Importantly, we show that treating business ownership simply as a binary outcome (i.e. self-employment or not self-employment) hides significant complexities in entrepreneurship differences between MexicanHispanics and whites. Our data show that Mexican-Hispanic males are more likely than white males to start-up new businesses in industries that require relatively low levels of educational attainment and that are not financially capital intensive and that MexicanHispanic business start-ups are concentrated in these industries.

\section{Previous Research}

In order to identify possible determinants of the Mexican-Hispanic selfemployment rate we build on the entrepreneurship literature addressing the business ownership choice. A major focus of the literature is on the role of access to financial 
capital: Do capital constraints shape self-employment entry and exit? This is often assessed by investigating whether exogenous changes in household net worth impact the decision to become a business owner, holding other factors constant. These stud ies typically find evidence of binding liquidity constraints in business start-ups (e.g. Evans and Leighton, 1989; Evans and Jovanovic, 1989; Lindh and Ohlsson, 1996). An exception is Hurst and Lusardi (2004). Furthermore, Holtz-Eakin, Joulfaian and Rosen (1994a) find that greater assets, measured as inheritances, lead to higher probability of business survival, again suggesting that liquidity constraints are binding. Furthermore, Bates (1990) finds that owner educational background is a major determinant of both business survival and the financial capital structure of small business start-ups. Other factors linked to the self-employment entry decision include managerial ability (e.g. Jovanovic, 1982) risk aversion (e.g. Kihlstrom and Laffont, 1979), non-pecuniary benefits of owning one's business (e.g. Blanchflower and Oswald, 1998) and intergenerational links, including parental wealth (Dunn and Holtz-Eakin, 2000).

These factors have also been linked to explaining low self-employment rates among African-Americans and Hispanics, or Latinos. Although differences in household net worth, education and family structure across groups have been found to partly explain differences in self-employment entry and exit rates (Fairlie, 1999; Hout and Rosen, 2000), differences in parental entrepreneurship appears to explain a significant proportion of the gap (Fairlie, 1999 and Hout and Rosen, 2000). The fact that a substantial proportion of Hispanics are immigrants, and possessing low levels of financial and human capital, as well as limited relevant business start-up information, is also a contributor to the self-employment gap (Fairlie and Meyer, 1996). 
Another aspect of financial capital constraints that may explain differences in business ownership is differential treatment in the credit market. Blanchflower, Levine and Zimmerman (2003) find that black-owned small businesses are more likely to be denied credit and, if approved, pay a one percentage point higher interest rate than whites, even after controlling for differences in creditworthiness. Credit constraints are likely to impact the types of industries that minorities seek to enter, and hence the industry composition of the minority business community, Bates (1995).

The only existing research, to our knowledge, directly addressing the lower selfemployment rates among Hispanics by studying business entry and exits is by Fairlie and Woodruff (2005), who utilize matched Current Population Survey data, and find that differences in education and wealth are key factors in explaining the low selfemployment rates among Mexican-Americans. Our nationally representative longitudinal data, the Survey of Income and Program Participation (SIPP), has the advantage of following individuals over a four year period, as well as more detailed information regarding assets and business ownership. The SIPP data also contains information on the industry of the firm. The latter is important since we address the role of industry the entrepreneur chooses and operates within in explaining the Mexican-Hispanic - white self-employment gap.

\section{Data}

Our data are derived from the 1996 panel of the Survey of Income and Program Participation (SIPP) and cover the 4 year period from 1996 to 1999. The 1996 SIPP 
survey is a rotating panel made up of 12 waves of data collected every four months for approximately 36,700 U.S. households. The 1996 panel over-sampled low-income households and hence sampling weights are used throughout our analysis, making the data nationally representative. As with previous SIPP panels, each wave contains both core questions, common to each wave, and topical questions that are not updated in each wave. In addition to the core variables, we use information from two topical modules: immigration (which includes information on country of origin as well as year of arrival) and assets and liabilities (containing wealth and asset data, collected each year in waves $3,6,9$ and 12).

The sample utilized is restricted to Mexican-Hispanic and non-Hispanic white males between the ages of 20 and 64 in the survey period. We do not restrict our sample to only full-time working individuals since a significant proportion of business entries are from non-employment. Concentrating this specific research on males simplifies the analysis somewhat since male labor supply issues are arguably less complicated. Furthermore, we restrict our sample to males for whom immigration status and wealth information are available, as well as to individuals who are observed in at least two consecutive years. The sample restrictions yield a sample of 135,596 observations, or 19,756 individuals. Lastly, we define an individual to be self-employed if he reported owning a business in the sample wave and hence use the terms business start- up and selfemployment entry interchangeably. 


\section{Self-Employment Entry}

The number of individuals who are self-employed is determined by the number of individuals who enter and exit self-employment. In this paper, we focus on differences in business start-ups between Mexican-Hispanics and whites. ${ }^{1}$ Importantly, we address the role of differences in the industry composition of entrepreneurs in explaining the relatively low Mexican-Hispanic self-employment rate.

Table 1 shows that the Mexican-Hispanic self-employment rate is 8.5 percent, close to half the self-employment rate among non-Hispanic whites, 16.1 percent. The lower self-employment rate among Mexican-Hispanics, relative to whites, partially reflect lower Mexican-Hispanic self-employment entry rates. Table 1 also shows selfemployment entry rates, defined as the probability of entering self-employment during a given year, conditional on not being self-employed the previous year. ${ }^{2}$ The table shows that Mexican-Hispanics have lower self-employment entry rates by about 0.3 percentage points, compared to non-Hispanic whites, 2.4 and 2.7 percent each. The table also indicates that slightly more than 10 percent of individuals who start their own business do so by coming from non-employment. This suggests that it is of some importance to not restrict the sample to working individuals.

The relatively small differences in self-employment entry rates between MexicanHispanics and whites suggest that the main source of the observed Hispanic-white self-

\footnotetext{
${ }^{1}$ See Lofstrom and Wang (2006) for an analysis of self-employment exits among Hispanic males.

${ }^{2}$ The entry rates shown in Table 1 appear to be consistent with previous research on self-employment entry. For example, Holtz-Eakin, Joulfaian and Rosen (1994a and 1994b) report four-year entry rates, 1981-1985, based on administrative data of 6.8 percent, quite similar to the sample period entry rate obtained with our definition of self-employment using the SIPP data with the above specified sample; about 8 percent. Some of the differences are likely to be due to changes in self-employment since the 1980's and our sample selection.
} 
employment gap is differences in self-employment exit rates. However, even though the differences in business entry rates are relatively small, this does not imply that they are unimportant and/or that minorities do not face additional business start-up constraints. We first demonstrate that the small self-employment entry rate difference helps explain a portion of the self-employment gap and then turn to examining potential start-up barriers.

One way to illustrate how small differences in entry rates have a meaningful impact on self-employment rates, and differences between groups, is to demonstrate what the self-employment gap would be if Mexican-Hispanics were as likely to enter selfemployment as whites, i.e. an increase in the Mexican-Hispanic self-employment entry rate by only 0.3 percentage points. Furthermore, we utilize the assumption that selfemployment is in steady-state and hence the self-employment rate can be expressed as the Entry Rate / (Entry Rate + Exit Rate), where we use the self-employment exit rates reported in Lofstrom and Wang (2006). In this hypothetical example, the MexicanHispanic self-employment rate would increase by slightly more than one percentage point and hence reduce the self-employment rate gap by that amount. In other words, this small difference in entry rates accounts for approximately 15 percent of the lower MexicanHispanic self-employment rate.

\section{Industries and Potential Entry Barriers}

The self-employment entry difficulties Mexican-Hispanics may face are possibly due to low endowments of human capital, as well as limited access to financial resources. Table 2 shows that educational attainment of Mexican-Hispanics is substantially below that of whites. For example, close to $1 / 2$ of self-employed Mexican-Hispanics have not 
completed high school and only 9 percent are college graduates. The corresponding proportions among non-Hispanic white entrepreneurs are 7 percent high school dropouts and 38 percent college graduates. Table 2 also shows that household wealth among Mexican-Hispanics is significantly below that of non-Hispanic whites. ${ }^{3}$ Whether the latter should be interpreted as an indication of limited access to financial capital or due to other factors, such as low schooling levels, is not clear. Nonetheless, there appear to be significant differences in human capital endowment, and possibly financial resources, between Mexican-Hispanics and whites. We address some of the consequences of these differences on self-employment next and particularly how small differences in selfemployment entry rates may disguise bus iness start-up barriers.

The type of business ownership is also of interest and related to potential barriers to enter self-employment. The SIPP data contain information on what type of business the individual owns, as well as business equity. These characteristics are shown in Table 3. The table shows that self-employed Mexican-Hispanics are substantially less likely to own an incorporated business than non-Hispanic whites. Furthermore, mean business equity is found to be lower among Hispanic owned businesses than white owned businesses. It is particularly low among Mexican-Hispanics, about $\$ 25,000$, compared to close to $\$ 90,000$ for the non-Hispanic whites. Although these observed characteristics may be the outcome of different selection into business ownership between minorities and whites (see e.g. Kawaguchi, 2005), they are also consistent with Hispanics facing additional capital constraints, relative to whites, as well as group differences in educational attainment.

\footnotetext{
${ }^{3}$ Household wealth is defined as the sum of financial assets and equity in home, vehicle and owned business.
} 
The relatively low educational attainment level of Mexican-Hispanics is likely to restrict access to certain industries (such as professional services, which includes physicians, dentists and lawyers) and may “push” Mexican-Hispanic entrepreneurs into less selective, educationally speaking, industries. If industries that require relatively high schooling levels to enter also have relatively high business survival rates, we may not observe large differences in business start-up rates but average exit rates will be higher for Mexican-Hispanics. Furthermore, if Mexican-Hispanics enter certain types of less well funded businesses, or industries, because they face limited access to capital, we may expect this to reveal itself in higher business failure rates, even though the selfemployment entry rates are not dramatically different. Clearly, it is quite challenging to address the latter issue, but the above discussion suggests that a closer look at industries is important in order to understand why Mexican-Hispanics are less likely to be business owners than non-Hispanic whites.

Clearly, potential business ownership constraints faced by minorities are typically not directly observable. However, they may manifest themselves in the choice of industry, or types of business, as discussed above. For example, if there are additional lending constraints faced by minorities, as suggested by Blanchflower, Levine and Zimmerman (2003) and Cavalluzzo, Cavalluzzo and Wolken (2002), we would expect to see fewer minorities in financial capital-intensive industries. As discussed above, however, some barriers to self-employment are observable. For example, given the substantial observed differences in educational attainment between Mexican-Hispanics and whites, many Hispanics effectively do not have access to certain human capital intensive industries. This can, at least partially, be addressed by simply controlling for 
schooling levels in regression models. However, Mexican-Hispanics'stock of human capital may be valued and/or perceived differently from non-Hispanics, suggesting that education may play different roles across ethnic/racial groups. Evidence of different roles of education in the U.S. labor market, in terms of schooling's impact on earnings, between immigrants and natives is found in Betts and Lofstrom (2000). Given the large proportion of immigrants among Mexican-Hispanics, this is relevant to the selfemployment decision, which is at least partially based on expected earnings.

The distribution of industries entrepreneurs operate in are substantially different between Mexican-Hispanics and whites. Table 4 shows the industry distribution for business owners, as well as mean years of schooling and business equity by these industries. The table shows that Mexican-Hispanics business owners are most likely to own a business in the construction industry, about 33 percent of Mexican-Hispanic entrepreneurs, which is also an industry with relatively low educational attainment and business equity. The construction industry is also the most common industry to own a business in among whites, but by roughly 13 percentage points fewer business owners. A large proportion of non-Hispanic whites own businesses in the professional services industry, slightly more than 16 percent. Only about 4 percent of Mexican-Hispanics own a business in this industry of the most highly educated entrepreneurs, where business owners have close to 18 years of schooling on average. Overall, it appears that MexicanHispanics are over-represented, relative to whites, in industries with lower educational attainment levels and business equity. The observed differences in the self-employed industry composition suggests that it is important to address the role of industries which 
vary in the ir human and financial capital requirements, as argued by Bates (1995), in analyzing self-employment differences between Mexican-Hispanics and whites.

\section{Self-Employment Entry by Industry Groups}

In the analysis below we attempt to tackle the above issues by analyzing selfemployment entry into specific industry groups. The groups are defined based on industry human and financial capital requirements.

A practical restriction we face is that the number of individuals in the industries specified in Table 4 is in some cases small, particularly by ethnicity, making relatively precise inference difficult. Instead, we define three industry categories based on human and financial capital requirements, or barriers, to enter the industry. Clearly, any classification into industry categories of entry difficulty, or barriers, is somewhat arbitrary ${ }^{4}$. Nonetheless, to determine whether an industry is a low, medium or highbarrier industry, we utilize the 1997 Annual Capital Expenditure Survey (ACES) to determine average fixed private capital by the 14 industries defined in Table 4 and the 2000 Census 5 percent Public Use Microdata Sample (PUMS) to determine entrepreneurs' educational attainment by industry. Based on the above data, we categorize Gardening/Landscaping, Construction, Retail trade and Repair services as low-barrier industries since all these industries display relatively low average educational

\footnotetext{
${ }^{4}$ We generated the results presented in Table 5 with two alternative definitions of the three industry groups as a robustness check of our definition. First, we define the highest of the low and mediumbarrier industries as medium and high respectively. This puts retail trade in the mediumbarrier industry and business services and transportations/communications in the high-barrier category. Our second alternative industry group definition puts the lowest of the medium and high-barrier industries in the low and medium groups respectively, which places agriculture in the low-barrier industry group while the real estate category is defined as a medium-barrier industry. Although the re-definitions change the reported entry rates and Hispanic-white gaps somewhat, the qualitative results and conclusions discussed in the paper appear robust to these alternative industry groupings. The results and tables generated utilizing the alternative definitions are not shown but are available upon requests from the authors.
} 
attainment levels (roughly around high school graduate or below) and average capital expenditures rank among the lowest (all are in the bottom 1/3). The medium-barrier category consists of firms in Agriculture, Manufacturing, Transportation/Communications, Wholesale trade, Business services, Personal services and Entertainment/Recreation services. These are industries in which entrepreneurs typically have at least some college education and/or average capital expenditures are in the mid-range amongst our industries. The high-barrier industry category consists of firms in the Finance/Insurance/Real estate and Professional/Related services industries. According to the 2000 Census, more than 85 percent of entrepreneurs in the Finance/Insurance/Real estate and Professional/Related industries have some college education while the 1997 ACES data show that businesses in the Finance/Insurance/Real estate industries have the highest average capital expenditures.

Lastly, the increase in the number of categories, or choices, (no entry, entry into a low-barrier industry, entry into a medium-barrier industry or entry into a high-barrier industry) also implies that the year-over-year probability an individual chooses to enter self-employment in a specific industry group, or not, is rather small. Hence, for the analysis below, we focus on the four-year sample period entry probabilities, i.e. the probability that an individual who was not self-employed during the first SIPP wave in 1996 becomes self-employed in the subsequent 11 waves.

We show the sample period self-employment entry rates by industry group separately for Mexican-Hispanics and whites in Table 5. The table reveals several interesting points. The probability a Mexican-Hispanic male will start-up a business in the low-barrier industry group over the sample period is 4.4 percent, while it is only 2.9 
percent for white males. That is, although Mexican-Hispanics are less likely to enter selfemployment than whites, by approximately 1.8 percentage points, they are 1.5 percentage points more likely to start-up a business in a low-barrier industry than whites. The picture is quite different when we analyze entry into medium and high-barrier industry groups. The probability that a Mexican-Hispanic will start his own business during the 1996-99 sample period in the medium-barrier industry group is 1.8 percent, almost $1 / 2$ of the selfemployment entry rate in this industry group among whites, 3.4 percent. The difference in the high-barrier industry self-employment entry rate is even starker. Only 0.2 percent of our sample of Mexican-Hispanics started a business in this industry group, compared to 1.9 percent among whites.

The classification of self-employment entry by industry groups shows that the lower self-employment entry rate among Mexican-Hispanics is due to lower business start-up rates in the medium- and high-barrier industries. The self-employment entry rates by industry group also show that Mexican-Hispanics are quite likely to start their own business. However, the business start-ups are concentrated in the least difficult industries to enter, as measured by human capital and financial resource requirements. Table 5 shows that about 2/3 of Mexican-Hispanic business start-ups are in low-barrier industries while only about $1 / 3$ of white business entries are in these industries. Almost all of the other observed Mexican-Hispanic business start-ups are in the medium-barrier industry group, approximately $1 / 3$ of all start-ups, while slightly more than 40 percent of white business start-ups are in this group. While only about 3 percent of newly entered Mexican-Hispanic self-employed males are in the high-barrier industry, almost $1 / 4$ of white business start-ups are in this industry category. It is quite clear from Table 5 that 
the types of businesses started up are quite different for Mexican-Hispanics and nonHispanic whites.

\section{Summary and Conclusions}

This paper contributes to the minority entrepreneurship research by analyzing self-employment among Mexican-Hispanics, an important and growing minority group which has been relatively overlooked in the entrepreneurship literature. Our data reveal that Mexican-Hispanic males are substantially less likely to be business owners, relative to whites. We investigate the causes of the Mexican-Hispanic - white differences in business ownership rates by analyzing self-employment entry rates, particularly the role of industries and potential barriers to business start-ups.

We observe relatively small differences in self-employment entry rates across groups. We argue that this should not be interpreted as Mexican-Hispanics do not face additional barriers to enter self-employment. We observe differences across groups in forms of businesses owned, i.e. incorporated or unincorporated, and industry composition. Although these differences are partially due to differences in factors such as educational attainment, they are also consistent with minority business start-up credit constraints which lead to less well funded small business and/or selection into less capital- intensive industries. Also, we show that relatively small differences in entry rates have a meaningful impact on the Mexican-Hispanic - white self-employment gap.

We discuss and examine the role of industries in further explaining differences in entrepreneurship between Hispanics and whites. Notably, we show that treating business 
ownership simply as a binary outcome (i.e. self-employment or not self-employment) hides significant complexities in self-employment differences across ethnic groups. We categorize firms into three industry groups based on human and financial capital requirements to enter the industry; low, medium and high-barriers to enter industries. This reveals that Mexican-Hispanics are more likely than whites to become business owners in the low-barrier industry group, the industry group where Mexican-Hispanic business start-ups are concentrated.

The observed lower self-employment entry rates among Mexican-Hispanics are due to lower entry rates into the relatively higher barrier industries. Although not addressed in this paper, we investigate in more detail the role of educational attainment and household wealth in a separate paper, see Lofstrom and Wang (2006). The analysis there indicates that differences in industry group self-employment entry rates are primarily due to lower educational attainment levels among Mexican-Hispanics, although differences in financial wealth appear to contribute to some extent. It also shown that the industry grouping utilized in this paper is very effective in explaining differences across ethnic groups in self-employment exit rates.

The findings in this paper, and Lofstrom and Wang (2006), are consistent with the hypothesis that the lower self-employment rate among Mexican-Hispanics, relative to whites, is at least partially due to human and financial capital start-up constraints. Particularly, the lower educational attainment levels among Mexican-Hispanics appear to restrict business start- ups to low-barrier industries. This points to the possibility that policies aimed at increasing the currently low average Mexican-Hispanic schooling levels may also succeed in increasing the Hispanic self-employment rate. Lastly, an important 
issue for future research is to assess whether there are differences in the success of selfemployed Mexican-Hispanics and whites within industry groups. The entry barriers addressed in this paper may also affect the success of Mexican-Hispanic entrepreneurs, which may be one of the mechanisms that leads to the observed low Mexican-Hispanic self-employment rate. 


\section{References}

Bates, Timothy. 1989. "The Changing Nature of Minority Business: A Comparative Analysis of Asian, Nonminority, and Black-Owned Businesses" The Review of Black Political Economy, 18, Fall: 25-42.

Bates, Timothy. 1990. "Entrepreneur Human Capital Inputs and Small Business Longevity," Review of Economics and Statistics 72 (4): 551-59.

Bates, Timothy. 1990. "Self-Employment Trends Among Mexican Americans", Working Paper, U.S. Census Economic Studies.

Bates, Timothy. 1993. Assessment of State and Local Government Minority Business Development Programs. Report to the U.S. Department of Commerce Minority Business Development Agency. Washington, D.C.: U.S. Department of Commerce.

Bates, Timothy. 1995. "Self-Employment Entry across Groups" Journal of Business Venturing, 10: 143-156

Bates, Timothy. 1997. Race, Self-Employment \& Upward Mobility: An Illusive American Dream, Washington, D.C.: Woodrow Wilson Center Press and Baltimore: John Hopkins University Press.

Betts, Julian R. and Magnus Lofstrom. 2000. "The Educational Attainment of Immigrants: Trends and Implications," in George J. Borjas ed. Issues in the Economics of Immigration, University of Chicago Press, for National Bureau of Economic Research, pp. 51-115.

Blanchflower, David G. 2004. "Self-Employment: More May Not Be Better”, NBER Working paper No. 10286.

Blanchflower, David G., P. Levine and D. Zimmerman. 2003. "Discrimination in the Small Business Credit Market", Review of Economics and Statistics, November, 85(4): 930-943

Blanchflower, David G. and Andrew J. Oswald. 1998. "What Makes an Entrepreneur?" Journal of Labor Economics, 16, 26-60.

Cavalluzzo, Ken, Linda Cavalluzzo, and John Wolken. 2002. "Competition, Small Business Financing, and Discrimination: Evidence from a New Survey," Journal of Business, Vol. 25 no. 4.

Dunn, T. and D. Holtz-Eakin. 2000. "Financial Capital, Human Capital, and the Transition to Self-Employment: Evidence from Intergenerational Links." Journal of Labor Economics, 18, 282-305. 
Evans, David S. and Boyan Jovanovic. 1989. "An Estimated Model of Entrepreneurial Choice under Liquidity Constraints." Journal of Political Economy, 97, 808-827.

Evans, David S. and Linda S. Leighton. 1989. "Some Empirical Aspects of Entrepreneurship". American Economic Review, 79, 519-35.

Fairlie, Robert W. and Christopher Woodruff. 2005. "Mexican-American Entrepreneurship" Paper presented at the $10^{\text {th }}$ Annual Meeting of the Society of Labor Economists, San Francisco, June 2005.

Fairlie, Robert W. 1999. "The Absence of the African-American Owned Business: An Analysis of the Dynamics of Self-Employment." Journal of Labor Economics, 17(1): 80-108.

Fairlie, Robert W. and Meyer, Bruce D. 1996. "Ethnic and Racial Self-Employment Differences and Possible Explanations.” Journal of Human Resources 31:757-93.

Holtz-Eakin, Douglas, David Joulfaian and Harvey S. Rosen. 1994a. "Sticking it Out: Entrepreneurial Survival and Liquidity Constraints." Journal of Political Economy, 102, 53-75.

Holtz-Eakin, Douglas, David Joulfaian and Harvey S. Rosen. 1994b. "Entrepreneurial Decisions and Liquidity Constraints" Rand Journal of Economics, 25, 334-47.

Hurst, Erik, and Annamaria Lusardi. 2004. "Liquidity Constraints, Household Wealth, and Entrepreneurship," Journal of Political Economy, 112(2): 319-347.

Hout, Michael and Harvey Rosen. 2000. "Self-Employment, Family Background, and Race,” Journal of Human Resources, 35(4), 670-692.

Kawaguchi, Daiji. 2005. "Negative Self Selection into Self-employment among African Americans," Topics in Economic Analysis \& Policy, 5(1).

Kihlstrom, Richard E. and Jean-Jacques Laffont. 1979. “A General Equilibrium Entrepreneurial Theory of Firm Formation Based on Risk Aversion" Journal of Political Economy, 87:4, 719-748.

Lindh, Thomas and Henry Ohlsson. 1996. "Self-Employment and Windfall Gains. Evidence from the Swedish Lottery". The Economic Journal, 106, 1515-1526.

Lofstrom, Magnus and Chunbei Wang. 2006. "Hispanic Self-Employment: A Dynamic Analysis of Business Ownership,” IZA Discussion Paper No. 2101, March 2006.

U.S. Census Bureau. 2006. Statistical Abstract of the United States. 
Table 1.

Self-Employment Rates and Transitions (in \%) by Race/Ethnicity.

\begin{tabular}{lcccc}
\hline & \multicolumn{2}{c}{ Mexican-Hispanics } & \multicolumn{2}{c}{ White (Non-Hispanics) } \\
& Percent & $\mathrm{N}$ & Percent & $\mathrm{N}$ \\
\hline Self-Employment Rate & 8.52 & 10,720 & 16.10 & 124,876 \\
& & & & \\
Self-Employment Entry & 2.36 & 9,618 & 2.65 & 103,204 \\
Entry from Wage/Salary & 2.09 & 8,328 & 2.59 & 89,557 \\
Entry from Unemployment & 6.01 & 316 & 9.41 & 1,520 \\
Entry from NILF & 5.16 & 1,008 & 4.73 & 12,760 \\
& & & &
\end{tabular}

Source: 1996 Survey of Income and Program Participation. Note, the self-employment entry rate sample size, N, refers to the number of observations where the person was not self-employed the previous year. 
Table 2.

Sample Statistics by Ethnicity/Race and Self-Employment (conditional on employment)

\begin{tabular}{|c|c|c|c|c|}
\hline & \multicolumn{2}{|c|}{ Mexican-Hispanics } & \multicolumn{2}{|c|}{ White (Non-Hispanics) } \\
\hline & Wage/Salary & Self-Employed & Wage/Salary & Self-Employed \\
\hline High School Dropout & 0.40 & 0.46 & 0.06 & 0.07 \\
\hline High School Graduate & 0.30 & 0.23 & 0.32 & 0.28 \\
\hline Some College & 0.24 & 0.22 & 0.31 & 0.27 \\
\hline College Graduate & 0.06 & 0.09 & 0.31 & 0.38 \\
\hline Age & 36.07 & 42.28 & 40.10 & 44.45 \\
\hline Married & 0.69 & 0.79 & 0.69 & 0.76 \\
\hline Number of Children & 1.59 & 1.60 & 0.85 & 0.90 \\
\hline Number of Persons in Household & 4.37 & 4.30 & 3.08 & 3.11 \\
\hline Urban Resident & 0.90 & 0.82 & 0.78 & 0.74 \\
\hline Immigrant & 0.49 & 0.50 & 0.03 & 0.03 \\
\hline Years Since Immigration* & 17.28 & 18.72 & 15.98 & 20.83 \\
\hline \multicolumn{5}{|l|}{ Total Annual Earnings } \\
\hline Mean & 23,040 & 22,246 & 39,023 & 46,866 \\
\hline Median & 19,610 & 16,640 & 32,036 & 29,889 \\
\hline Hours Work/Week & 41.32 & 46.24 & 43.44 & 50.49 \\
\hline Job Tenure & 6.42 & N/A & 8.79 & N/A \\
\hline Business Tenure & N/A & 6.81 & N/A & 9.63 \\
\hline \multicolumn{5}{|l|}{ Household Wealth } \\
\hline Mean & 45,828 & 81,465 & 135,693 & 304,735 \\
\hline Median & 15,050 & 36,537 & 57,141 & 135,096 \\
\hline Annual Household Asset Income & 125 & 151 & 632 & 1,452 \\
\hline Number of Individuals & 1,436 & 169 & 14,946 & 3,205 \\
\hline Sample Size & 8,133 & 913 & 87,775 & 20,102 \\
\hline
\end{tabular}

Source: 1996 Survey of Income and Program Participation. * Conditional on being an immigrant. 
Table 3.

Business Ownership Characteristics, Percent of Business Owners and Sample Means, by Race/Ethnicity.

\begin{tabular}{lcc}
\hline & $\begin{array}{c}\text { Mexican } \\
\text { Hispanic }\end{array}$ & $\begin{array}{c}\text { White } \\
\text { (Non-Hispanic) }\end{array}$ \\
\hline Business Type (\%) & 7.4 & 27.4 \\
Unincorporated & 69.1 & 49.2 \\
Unincorporated & 10.3 & 11.1 \\
Household Business Partner & 6.2 & 11.6 \\
Business Equity (\$) & & \\
\hline Source: 1996 Survey of Income and Program Participation. &
\end{tabular}

Source: 1996 Survey of Income and Program Participation.

Table 4.

Business Ownership - Industry Characteristics and Distribution, by Race/Ethnicity.

\begin{tabular}{|c|c|c|c|c|}
\hline & \multicolumn{2}{|c|}{$\begin{array}{c}\text { Industry Characteristics } \\
\text { Sample Mean }\end{array}$} & \multirow[t]{2}{*}{$\begin{array}{l}\text { Mexican } \\
\text { Hispanic }\end{array}$} & \multirow[t]{2}{*}{$\begin{array}{c}\text { White } \\
\text { (Non-Hispanic) }\end{array}$} \\
\hline & $\begin{array}{l}\text { Years of } \\
\text { Schooling }\end{array}$ & $\begin{array}{c}\text { Business } \\
\text { Equity (\$) }\end{array}$ & & \\
\hline Agriculture/Forestry/Fisheries & 13.0 & 176,169 & 5.5 & 9.4 \\
\hline Construction & 12.4 & 64,595 & 33.1 & 19.9 \\
\hline Manufacturing & 13.8 & 106,813 & 3.9 & 5.6 \\
\hline Transportation/Communications & 12.3 & 59,313 & 6.6 & 4.6 \\
\hline Wholesale Trade & 14.0 & 139,648 & 1.1 & 5.4 \\
\hline Retail trade & 13.3 & 71,833 & 13.9 & 10.0 \\
\hline Finance/Insurance/Real estate & 15.0 & 112,720 & 3.0 & 5.9 \\
\hline Business Services & 14.5 & 63,265 & 3.0 & 8.5 \\
\hline Personal Services & 13.9 & 57,700 & 3.8 & 3.1 \\
\hline Entertainment/Recreation Services & 14.6 & 20,587 & 2.0 & 4.2 \\
\hline Professional/Related Services & 17.7 & 98,527 & 3.9 & 16.6 \\
\hline Gardening/Landscaping & 11.5 & 63,168 & 6.8 & 2.0 \\
\hline Repair Services & 11.7 & 26,275 & 13.5 & 4.4 \\
\hline
\end{tabular}

Source: 1996 Survey of Income and Program Participation. 
Table 5.

Self-Employment Entry Probabilities by Industry Group, Full Sample Period, by Race/Ethnic ity.

Mexican

White

Hispanic

(Non-Hispanic)

Sample Period

Transition Probabilities

No Entry

93.7

91.9

Self-Employment Entry

6.3

8.1

Industry Group Entry Probability

Entry into Low-barrier Industry ${ }^{\text {i) }}$

4.4

Entry into Medium-barrier Industry ${ }^{\text {ii) }}$

1.8

3.4

Entry into High-barrier Industry ${ }^{\text {iii) }}$

0.2

1.9

Number of Individuals

1,436

14,946

Source: 1996 Survey of Income and Program Participation.

i) Gardening/Landscaping, Construction, Retail trade or Repair services

ii) Agriculture, Manufacturing, Transportation/communications, Wholesale trade, Business services, Personal services, Entertainment/recreation services

iii) Finance/Insurance/Real estate, Professional/Related services 